\title{
Acinetobacter anitratus
}

National Cancer Institute

\section{Source}

National Cancer Institute. Acinetobacter anitratus. NCI Thesaurus. Code C86089.

A species of aerobic, Gram neg ative, rod shaped bacteria assigned to the phylum

Proteobacteria. This bacteria is nonmotile, oxidase negative, catalase positive and produces acid from glucose. A. anitratus is thought to be a commensal organism of the skin but may become pathogenic in patients with underlying conditions. 